\title{
HIV/AIDS and human rights in legislation of the Republic of Serbia
}

\author{
Miljana Grbic ${ }^{*}$, Vojin Dimitrijevic ${ }^{2}$, Nenad Petkovic ${ }^{3}$, Ana Maricic ${ }^{4}$, Judita Reichenberg ${ }^{5}$, Jelena Zajeganovic ${ }^{5}$, \\ Milos Stojanovic ${ }^{1}$, Rade Grbic ${ }^{6}$ \\ From $16^{\text {th }}$ International Symposium on HIV and Emerging Infectious Diseases \\ Marseille, France. 24-26 March 2010
}

\section{Background}

The aim of the abstract is to present a short overview of the legislation of the Republic of Serbia related to HIV/ AIDS and suggestions for improvement in accordance with the international regulations and practices.

\section{Methods}

Analysis of the laws and by-laws of the Republic of Serbia in connection with human rights of persons living with HIV in comparation to the key international treates and other international documents pertaining to HIV/ AIDS issues.

\section{Results}

Protection and advancement of the human rights are of crucial importance for prevention of the HIV epidemic. The best efforts of the international and national communities aiming at promotion of the human rights and prevention of discrimination, provision of adequate health care for the persons living with HIV and dissemination of information to the general public, have not yet succeeded in overcoming of the stereotypes and securing adequate protection of human rights of the persons living with HIV.

\section{Discussion}

Analysis of the current legislation in Serbia indicates that there are ways, though mostly indirect, to protect the interests of the vulnerable persons. However, most of these provisions were originally drafted with other vulnerable groups in mind and can apply to the group under discussion only if the courts and other relevant

\footnotetext{
* Correspondence: grbicm@aol.com
}

'UNAIDS, Belgrade, Serbia bodies show willingness to interpret the existing regulations in a way that is most favorable for this group.

It would be a much better solution to have special regulations that would directly protect those human rights of the AIDS patients and the persons living with HIV that are violated most frequently. These are the rights that are in general protected by the Constitution of the Republic of Serbia and international covenants signed by the Republic of Serbia, most important among them being the International Covenant on Civil and Political Rights, the International Covenant on Economic and Social Rights and the European Convention on Human Rights. These are the right to life, the right to privacy, the right to personal dignity and reputation, nondiscrimination, the right to work under equal conditions, the right to the highest attainable standard of living, the right to health care, the right to equal reward for equal work, the right to social insurance, the right to exercise parental rights, the right to education, the right of movement and settlement, the right of expression, freedom of thought and conscience and freedom of participation in social and political life. Some of these are so-called solidarity rights and cannot be exercised by means of court decisions. They must be guaranteed by an appropriate social policy and the best efforts of government bodies. Therefore they cannot be defined solely as individual rights, but as obligations of government bodies.

The general recommendation, agreed upon by the legal experts is that the best solution available is to pass a special law (lex specialis) that will regulate most of the issues in connection with HIV/AIDS. This recommendation is based on the finding that there are numerous regulations that indirectly pertain to HIV/AIDS, but they are scattered over too many different laws and bylaws and contain no specific references to HIV. That 
might explain the small number of the HIV/AIDS related cases before the courts in Serbia. A special law on HIV/AIDS could replace or amend the provisions contained in the existing laws and clearly regulate the legal relations between different parties as required, taking into consideration the specific requirements of the HIV/AIDS related cases.

Author details

'UNAIDS, Belgrade, Serbia. 'Beogradski centar za ljudska prava, Belgrade, Serbia. ${ }^{3} \mathrm{Q}-k$ lub, Belgrade, Serbia. ${ }^{4}$ Ministry of Justice, Belgrade, Serbia.

${ }^{5}$ UNICEF, Belgrade, Serbia. ${ }^{6}$ Medical Faculty Pr, Pristina, Serbia.

Published: 11 May 2010
doi:10.1186/1742-4690-7-S1-P160

Cite this article as: Grbic et al:: HIV/AIDS and human rights in legislation of the Republic of Serbia. Retrovirology 2010 7(Suppl 1):P160.
Submit your next manuscript to BioMed Central and take full advantage of:

- Convenient online submission

- Thorough peer review

- No space constraints or color figure charges

- Immediate publication on acceptance

- Inclusion in PubMed, CAS, Scopus and Google Scholar

- Research which is freely available for redistribution

Submit your manuscript at www.biomedcentral.com/submit 